\title{
Sources of organic carbon supporting the food web of an arid zone
}

\section{floodplain river}

\section{STUART E. BUNN ${ }^{\mathrm{a}, \mathrm{b}}$, PETER M. DAVIES ${ }^{\mathrm{c}}$ AND MICHELLE WINNING ${ }^{\mathrm{a}}$}

${ }^{a}$ Cooperative Research Centre for Freshwater Ecology,

Centre for Catchment and In-Stream Research,

Faculty of Environmental Sciences, Griffith University,

Nathan, Queensland, Australia 4111.

${ }^{b}$ Corresponding author

(ph:07 3875 7407; fax: 073875 7615; email: s.bunn@mailbox.gu.edu.au)

${ }^{\mathrm{c}}$ Centre of Excellence in Natural Resource Management,

The University of Western Australia,

Albany, Western Australia 6330.

Key words: primary production, stable isotope analysis, phytoplankton, cyanobacteria, waterholes, dryland rivers 


\section{SUMMARY}

1. Many Australian inland rivers are characterised by vast floodplains with a network of anastomosing channels that interconnect only during unpredictable flooding. For much of the time, however, rivers are reduced to a string of disconnected and highly turbid waterholes. Given these features, we predicted that aquatic primary production would be light limited and the riverine food web would be dependent on terrestrial carbon from floodplain exchanges and direct riparian inputs.

2. To test these predictions, we measured rates of benthic primary production and respiration and sampled primary sources of organic carbon and consumers for stable isotope analysis in several river waterholes at four locations in the Cooper Creek system in central Australia.

3. A conspicuous band of filamentous algae was observed along the shallow littoral zone of the larger waterholes. Despite the high turbidity, benthic gross primary production in this narrow zone was very high $\left(1.7-3.6 \mathrm{~g} \mathrm{C} \mathrm{m}^{-2} \mathrm{day}^{-1}\right)$, about two orders of magnitude greater than that measured in the main channel.

4. Stable carbon isotope analysis confirmed that this "bath-tub ring" of algae was the major source of energy for aquatic consumers, ultimately supporting large populations of crustaceans and fish. Variation in the stable carbon and nitrogen isotope signatures of consumers suggests that plankton was the other major primary source.

5. Existing ecosystem models of large rivers often emphasize the importance of longitudinal or lateral inputs of terrestrial organic matter as a source of organic carbon for aquatic consumers. Our data suggest that, despite the presence of large 
amounts of terrestrial carbon, there was no evidence of it being a significant contributor to the aquatic food web in this floodplain river system.

\section{Introduction}

Aquatic invertebrates, fish and other consumers in small forested streams are considered to be strongly dependent on inputs of carbon and nutrients from the surrounding catchment, especially from the fringing riparian zone (Cummins, 1974; Vannote et al., 1980; Gregory et al., 1991). In-stream primary production is often limited by shading from the dense riparian canopy (Feminella, Power \& Resh, 1989; Boston \& Hill, 1991) and, with some exceptions (e.g. Rosenfeld \& Roff, 1992; Bunn, Davies \& Mosisch, 1999), contributes little to the stream food web. In more sparsely vegetated biomes and in larger streams and rivers, however, this direct riparian regulation of in-stream primary production is markedly reduced and aquatic plants may provide an important source of organic carbon for consumers (Finlay, 2001).

In the case of larger river systems, however, our understanding of these fundamental ecosystem processes is poor in comparison to their small forest stream counterparts (Johnson, Richardson \& Naimo, 1995). Current models of large river ecosystem function vary considerably in their predictions of the relative importance of terrestrial and in-stream production to aquatic food webs. The river continuum concept (RCC) (Vannote et al., 1980) emphasizes the importance of terrestrial carbon and nutrients "leaked" from upstream processes to the structure and function of lowland river reaches. Middle-order reaches, where the direct effects of riparian shading are diminished, may have an increased dependence on in-stream primary production. However, fine 
particulate organic matter is thought to be the principal carbon source supporting food webs in downstream reaches, and much of this is considered to be derived from upstream processing. Direct inputs of leaf litter and other coarse particulate organic matter from adjacent riparian vegetation are thought to be minor and, in larger rivers, in-stream primary production is limited by turbidity and light attenuation associated with depth (Vannote et al., 1980).

In contrast, the flood-pulse concept (FPC) (Junk, Bayley \& Sparks, 1989; Bayley, 1995) emphasizes the importance of lateral river-floodplain exchanges and proposes that riverine food webs are more dependent on production derived from the floodplain than on organic matter transported from tributaries upstream. During floods, aquatic animals migrate out onto the floodplain and exploit newly available habitats and their resources. As the floodwaters recede, carbon and nutrients together with newly produced animal biomass are returned to the main river channel (Johnson et al., 1995).

The riverine productivity model (RPM) provides an alternative view of ecosystem function in large rivers (Thorp \& Delong, 1994), and highlights the importance of local in-stream production (phytoplankton, benthic algae, and other aquatic plants) and, to a lesser extent, direct inputs of organic matter from the adjacent riparian zone. Thorp and Delong (1994) further argue that the previous two models of large river ecosystems underestimate the role of autochthonous sources and have over-emphasized the relative importance of terrestrial organic matter from both headwater streams (RCC) and floodplains (FPC). Although the RPM was originally proposed for highly regulated river systems that have been effectively isolated from their floodplains, Thorp and Delong (in press) propose that this model may also be more broadly applicable to unregulated, floodplain rivers. 
Many large inland rivers in Australia feature extensive floodplains and a network of anastomosing channels and distributaries that provide a far greater terrestrial-water interface than would occur with a single large channel (Walker, Sheldon \& Puckridge, 1995). The rivers have highly variable and unpredictable flow regimes (Puckridge et al., 1998; Thoms \& Sheldon, 2000) and, when they do flow, often occupy vast floodplains (Graetz, 1980). Perhaps not surprisingly, the FPC has been thought to provide an appropriate framework for understanding ecosystem processes in these rivers (Walker et al., 1995). However, although renowned for episodic floods, these dryland rivers (sensu Davies et al., 1995) exist for much of the time as a string of disconnected and highly turbid waterholes that act as refugia for aquatic organisms and other wildlife dependent on permanent water (Morton, Short \& Baker, 1995; Bunn \& Davies, 1999). The river water remains highly turbid, even during the long periods between flood flows.

Given these features, we predicted that the aquatic food web of dryland rivers would be dependent on energy and nutrients derived from extensive floodplain exchange during floods, and by continual input from riparian vegetation along the vast network of channels during the dry. We also predicted that aquatic plant production should be limited by low light penetration in the highly turbid water and thus make only a minor contribution to the aquatic food web. To test these predictions, we measured rates of benthic primary production and respiration and sampled primary sources of organic carbon and consumers for stable isotope analysis in several waterholes at four locations within the Cooper Creek system in central Australia. 


\section{Methods}

Study sites

Cooper Creek, formed by the confluence of the Thomson and Barcoo rivers, is the one of the major rivers of the Lake Eyre Basin in central Australia, draining an area of approximately 296,000 $\mathrm{km}^{2}$, from the Great Dividing Range in Queensland to Lake Eyre in South Australia (Anon., 1998; Fig. 1). The catchment lies in the arid region of Australia and much of the area receives less than $400 \mathrm{~mm}$ average annual rainfall (Anon., 1998). Although rainfall in this region is generally associated with summer monsoons, it has a very high inter-annual variability and the Cooper has one of the most variable and unpredictable flow regimes of any river in the world of comparable size (Knighton \& Nanson, 1994; Puckridge et al., 1998; Knighton \& Nanson, 2001). The average annual discharge at Windorah is approximately 3.3 million ML. However, in the 50 years of flow records from 1939 - 1988 there have been significant periods of no flow, with the longest in 1951/52 lasting 21 months, and several floods with the largest discharge in 1974 of more than 23 million ML (Anon., 1998).

Like most dryland rivers in this region, the Cooper catchment is characterised by a network of anastomosing channels and distributaries that interconnect only during episodic floods and approximately $35 \%$ of the catchment is considered to be floodplain (Graetz, 1980; Gibling, Nanson \& Maroulis, 1998). These floods can cover tens of thousands of square kilometers and take many weeks to travel down the extensive floodplain system of channels and wetlands. For example, the April 1990 flood inundated some $26,000 \mathrm{~km}^{2}$ downstream of the junction of the Thomson and Barcoo rivers (Anon., 1998). Mean annual evaporation exceeds $3 \mathrm{~m}$ and, together with transpiration and groundwater recharge, result in substantial transmission losses below 
Windorah that can account for more than two thirds of the discharge by the time it reaches Innamincka, on the South Australian border (Fig. 1; Anon., 1998).

Floodplain vegetation in these areas consists of short grass and forb associations and lignum associations (Boyland, 1984; Capon, 1998). Woody vegetation (river red gum Eucalyptus camaldulensis, coolibah E. coolibah, and melaleucas Melaleuca linariifolia) is mostly confined to a narrow riparian fringe slightly elevated above the floodplain and often only a few trees in width. The banks are generally steep and the water surface during the extended dry periods is generally several metres lower than the riparian zone. Depending on channel orientation (largely north/south), there can be considerable shading of the waterhole by the banks and vegetation during the early morning and late afternoon.

Three sites were chosen at each of four study locations on the Cooper Creek and its major tributaries (Table 1, Fig. 1). Three waterholes were sampled on Kyabra Creek, one of the major eastern tributaries of the Cooper, at One-mile waterhole (ID46), Springfield homestead waterhole (ID47) and Moonbang Creek (ID48), a small tributary of Kyabra Creek. The large Murken waterhole (ID49) on the Cooper main channel near Windorah was sampled together with an adjoining waterhole on a small distributary (ID50). A third site was sampled on the nearby Mayfield homestead waterhole (ID51). Two sites were sampled on the large Tanbar waterhole, at the homestead (ID52) and bottom crossing (ID53), and a third site was sampled on a small waterhole on one of the nearby distributary channels (ID54). Three waterholes were also sampled on the Barcoo River in the Barcoo-Welford National Park, at Rosehill (ID55), the shearing shed (ID56), and homestead (ID57) (Table 1, Fig. 1). 
All sites were sampled during a no-flow period in May 1997 and the sites at Mayfield and Kyabra were also sampled during similar no-flow conditions in September 1996. A small flood event occurred between these sample times, in February/March $1997\left(\mathrm{Q}_{\max }=1302 \mathrm{~m}^{3} \mathrm{~s}^{-1}\right.$ on the Thomson River at Longreach, Station 003202A $)$. However, with the exception of one other small flood $\left(\mathrm{Q}_{\max }=1196 \mathrm{~m}^{3} \mathrm{~s}^{-1}\right)$ in March 1994, little flow occurred between the sampling period and the last floods in April 1990 $\left(\mathrm{Q}_{\max }=8115 \mathrm{~m}^{3} \mathrm{~s}^{-1}\right)$ and February $1991\left(\mathrm{Q}_{\max }=4096 \mathrm{~m}^{3} \mathrm{~s}^{-1}\right)($ Queensland Department of Natural Resources and Mines, unpublished flow data).

Only the largest of the waterholes (Tanbar, Springfield homestead, and Murken) retain permanent water for many years without flow, though even these have been known to dry to a few shallow pools after extended dry periods. The small distributary sites adjoining Murken waterhole (ID50) and Tanbar waterhole (ID54), and particularly Moonbang Creek (ID48) were the most ephemeral of the waterholes sampled. All have been completely dry on more than one occasion since our sampling began in 1996.

Turbidity was consistently high at all sites during the dry with Secchi depths of ranging from $6 \mathrm{~cm}$ (Murken) to $15 \mathrm{~cm}$ (Tanbar). High turbidity is a characteristic feature of these systems with average Secchi values of 5 to $6 \mathrm{~cm}$ recorded throughout the Cooper (Bailey, 2001). Salinities are generally low with recorded conductivities ranging from 49-305 $\mu \mathrm{S} \mathrm{cm}^{-1}$ at $25^{\circ} \mathrm{C}$ (mean 119) for the Thomson River and $43.5-827 \mu \mathrm{S} \mathrm{cm}^{-1}$ (mean 205) for the Barcoo River (Bailey, 2001).

\section{Benthic metabolism}

Benthic gross primary production (GPP) and respiration $\left(\mathrm{R}_{24}\right)$ were measured at each site by monitoring dissolved oxygen within in situ perspex chambers over 24 hours (e.g. Bott 
et al., 1978, Bunn et al. 1999). Open-bottom perspex chambers $($ diameter $=29.5 \mathrm{~cm}$, height $=35 \mathrm{~cm}$ ) were sealed by pushing at least $10 \mathrm{~cm}$ into the soft substrate. All chambers had a central port for the polarographic oxygen sensor (TPS model 601) and side ports for a $12 \mathrm{~V}$ recirculating pump. Dissolved oxygen and temperature within each chamber was monitored electronically over at least $24 \mathrm{~h}$ at 10 -minute intervals and stored in a data logger (Wesdata model 389). These data were converted into units of carbon assuming a photosynthetic quotient of one (Lambert, 1984; Bender et al., 1987) and 1 $\mathrm{mg} \mathrm{O}_{2}=0.375 \mathrm{mg} \mathrm{C}$. After the end of the measurement period, the volume of water enclosed by each chamber was measured in situ to determine absolute rates of metabolism.

Rates of benthic metabolism were determined for two major habitats; the shallow littoral zone with a visible band of benthic algae and the deeper $(>35 \mathrm{~cm})$ main channel. Where possible at littoral sites, the chambers were pushed deep into the substrate so that measurements were made in as shallow water as possible. The mean depth of the littoral samples was $18 \mathrm{~cm}(\mathrm{SEM}=2.6 \mathrm{~cm})$. Replicate chambers were deployed in each habitat at each site and time, however, in some instances data from one of the replicates was lost due to logger or pump failure. The proportion of each habitat was estimated for several transects across the channel at each site. Mean values of GPP and P/R were scaled-up to overall waterhole values by determining the proportional representation of each habitat (littoral or channel).

Dissolved oxygen and temperature were also measured at 10 minute intervals in the surface water, mid-channel at each site over the same $24 \mathrm{hr}$ period using a TPS (model 601) polarographic oxygen sensor and a data logger (Wesdata model 389). 
Differences in benthic metabolism at each area, season and habitat were tested by a three-way ANOVA. Data were, where necessary, transformed prior to analyses and the magnitude of treatment effects was calculated to determine the relative importance (as a percentage) of the significant main effects (Winer, 1971).

\section{Collection of primary sources and consumers}

Major primary sources of organic carbon (terrestrial and aquatic) were collected from each site and, in the case of the Mayfield sites only, on both occasions. Newly abscised leaves from the major riparian trees (mostly Eucalyptus camaldulensis and E. coolibah) were collected by hand. Samples of benthic detritus were collected with a kick net and wet-sieved into fine $(250 \mu \mathrm{m}-1 \mathrm{~mm})$ and coarse $(>1 \mathrm{~mm})$ particulate organic matter (FPOM and CPOM) fractions. Benthic algal samples were collected from the shallow littoral margins, either directly off the mud surface or from woody debris. Because of the high suspended sediment and presence of other organic debris it was not possible to obtain samples of phytoplankton.

The waterholes teemed with snails (Viviparidae: Notopala sublineata), large shrimps (Palaemonidae: Macrobrachium australiense) and crayfish (Parastacidae: Cherax destructor). We sampled these conspicuous consumers with a small seine net and benthic traps. However, very few aquatic insects were found, even using a kick-net (250 $\mu \mathrm{m}$ mesh). Those collected included odonate larvae (mainly Gomphidae), beetles (Dytiscidae) and, in some leaf packs, chironomid larvae (Chironominae). We also collected freshwater clams (Corbiculinidae: Corbiculina) and mussels (Hyriidae: Velesunio spp) by hand. Zooplankton (mostly calanoid copepods) was sampled at dusk by towing a $250 \mu \mathrm{m}$ plankton net across the surface of the waterhole. 
Several species of native fish (bony bream Nematalosa erebi, rainbowfish Melanotaenia splendida tatei, smelt Retropinna semoni, yellowbelly Macquaria sp., Barcoo grunter Scortum barcoo, glass perchlet Ambassis mulleri, catfish Neosilurus argenteus and N. hyrtlii, spangled perch Leiopotherapon unicolor, gudgeons Hypseleotris spp.) and one introduced species (Gambusia affinis) were collected by seine net. Small samples of shell were removed from two turtles (Emydeura macquarii) caught in September 1996 and the animals returned alive to the waterholes.

Where possible, three replicate samples of each source and consumer were collected from each site. Animal and plant samples were refrigerated immediately and then frozen as soon as possible and stored for isotope analysis.

\section{Sample preparation and analysis}

Primary sources were rinsed in distilled water in the laboratory and oven-dried at $60^{\circ} \mathrm{C}$ for $36-48 \mathrm{~h}$. The dried material was then ground to a powder-like consistency in a ring grinder.

Macrobrachium exoskeletons and mollusc shells were removed to prevent possible contamination from non-dietary carbonates. The digestive tracts of Macrobrachium were also removed as they could represent a significant source of contamination from unassimilated material. Samples of Cherax muscle tissue were taken from crayfish claws or, in the case of smaller individuals, from the tail. Half of each zooplankton sample collected was treated in $10 \% \mathrm{HCl}$ for approximately two hours to remove carbonates from exoskeletons for $\delta^{13} \mathrm{C}$ analysis. The remaining sample was not treated in acid and was used for $\delta^{15} \mathrm{~N}$ analysis (Bunn, Loneragan \& Kempster, 1995). Aquatic 
insects were prepared whole and pooled for each site. Macrobrachium, snail and clam samples were also pooled for each site (8 - 30 individuals).

Samples of muscle tissue were filleted from each fish, in each case recording total body length. Most fish samples analyzed were from single individuals, however, in the case of small specimens, a few individuals (2-15) were pooled. Samples of liver and bone were also removed from eight of the larger predatory fish (four yellowbelly Macquaria and four spangled perch Leiopotherapon) to examine possible temporal changes in isotope ratios associated with shifts in diet (Hesslein, Hallard \& Ramlal, 1993). All animal samples were oven-dried at $60^{\circ} \mathrm{C}$ for $24 \mathrm{~h}$ and ground by hand with a mortar and pestle.

Dried, ground samples were oxidized at high temperature and the resultant $\mathrm{CO}_{2}$ and $\mathrm{N}_{2}$ were analyzed for $\% \mathrm{C}, \% \mathrm{~N}$ and stable isotope ratios with a continuous-flow isotoperatio mass spectrometer (Europa Tracermass and Roboprep, Crewe, England). Ratios of ${ }^{13} \mathrm{C} /{ }^{12} \mathrm{C}$ and ${ }^{15} \mathrm{~N} /{ }^{14} \mathrm{~N}$ were expressed as the relative per mil (\%o) difference between the sample and conventional standards (PDB carbonate and $\mathrm{N}_{2}$ in air) where:

$$
\begin{aligned}
& \delta X=\left(R_{\text {sample }} / R_{\text {standard }}-1\right) \times 1000(\%) \\
& \text { Where } X={ }^{13} \mathrm{C} \text { or }{ }^{15} \mathrm{~N} \text { and } \mathrm{R}={ }^{13} \mathrm{C} /{ }^{12} \mathrm{C} \text { or }{ }^{15} \mathrm{~N} /{ }^{14} \mathrm{~N}
\end{aligned}
$$

Measurement precision was approximately 0.1 and $0.3 \%$ for ${ }^{13} \mathrm{C} /{ }^{12} \mathrm{C}$ and ${ }^{15} \mathrm{~N} /{ }^{14} \mathrm{~N}$, respectively.

Simple relationships between $\delta^{13} \mathrm{C}$ and $\delta^{15} \mathrm{~N}$ signatures of fish, and between stable isotope signatures and fish size were examined using Pearson correlations. Where possible, a three-source mixing model using $\delta^{13} \mathrm{C}$ and $\delta^{15} \mathrm{~N}$ signatures of CPOM, plankton and benthic algae was used to estimate their relative importance to major consumers (Phillips, 2001; Phillips \& Gregg, 2001). At most sites, however, a two- 
source linear mixing model based on $\delta^{13} \mathrm{C}$ signatures of $\mathrm{CPOM}$ and benthic algae was used (Bunn, Davies \& Kellaway, 1997; Phillips, 2001).

\section{Results}

\section{Production and respiration}

The shallow littoral margins of the larger waterholes were characterised by a conspicuous, albeit, restricted band of epipelic filamentous algae, composed largely of blue-green algae (Schizothrix), green algae (Spirogyra and Oedogonium), and some diatoms (e.g. Navicula, Melosira). This algal zone had consistently high rates of both gross primary production (GPP) and respiration $\left(\mathrm{R}_{24}\right)$ (Table 2$)$. The high rates of $\mathrm{R}_{24}$ are undoubtedly the result of high algal respiration, rather than from decomposition of terrestrial organic matter, given the observed strong relationship between GPP and $R_{24}$ $\left(\mathrm{r}^{2}=0.87, \mathrm{p}<0.001\right)$.

In contrast, benthic production and respiration in the deeper channels were both low $\left(<90 \mathrm{mg} \mathrm{C} \mathrm{m}^{2} \mathrm{day}^{-1}\right.$ ) (Table 2). The P/R ratios (GPP: $\mathrm{R}_{24}$ ) showed that the littoral region of the waterholes was a major producer of carbon (i.e. $\mathrm{P} / \mathrm{R}>1$ ) whereas the midchannel habitat was a net consumer $(\mathrm{P} / \mathrm{R}<1)$. Even though the shallow littoral zone of the permanent waterholes represented between $4 \%$ (Tanbar) and $8 \%$ (Barcoo) of the total benthic habitat, primary production was so high that almost all of the waterholes were producers of organic carbon. There was little inter-annual or site differences in benthic metabolism and by far the most variation in the ANOVA model was explained by habitat differences (Table 3 ). 


\section{Stable isotope analysis of the food web}

Benthic algae were consistently more ${ }^{13} \mathrm{C}$-enriched than any other primary sources, though showed considerable variability across the sites (-14.5 to $-24.2 \%$, Table 4$)$. Mean $\delta^{13} \mathrm{C}$ values for benthic algae at the Mayfield sites were also slightly less enriched in the May 1997 sampling period compared to September 1996. Because of this variability, and the potential flow-on effects to the food web, comparisons of source and consumer signatures were only relevant within each site and sampling time. For this reason, all isotope data are presented for each site within location (Tables 4 and 5) and data from only one site per location has been plotted (Figure 2). In the latter, stable isotope values for primary sources are shown as boxes delineated by \pm 1 SE around the mean and consumers are shown as individual values or as means $\pm 1 \mathrm{SE}$, where $n=3$.

Samples of benthic coarse particulate organic matter (CPOM) had similar mean $\delta^{13} \mathrm{C}$ values $(-26.8$ to $-32.7 \%$ ) to leaves collected from riparian trees (-26.6 to $-31.6 \%$ ) and showed less variability in $\delta^{15} \mathrm{~N}$ values (Tables $4 \& 5$ ). Benthic fine particulate organic matter (FPOM), however, was typically 3-6 \%o more ${ }^{13} \mathrm{C}$-enriched than CPOM, suggesting a potential contribution of algal carbon (Table 4, Fig. 2).

Zooplankton samples were also relatively ${ }^{13} \mathrm{C}$-depleted compared with benthic algae with similar values to terrestrial organic matter (Table 4) but were more ${ }^{15} \mathrm{~N}$-enriched, considerably so at some sites (e.g. Mayfield and Barcoo-Welford, Table 5). Unfortunately, no plankton samples were collected at the Kyabra sites.

Mussels and clams had carbon isotope signatures consistent with either a terrestrial carbon or plankton source (Table 4, Fig. 2), but were considerably ${ }^{15} \mathrm{~N}$-depleted in comparison to the latter (Table 5). Although snails at Murken waterhole had carbon and nitrogen isotope signatures consistent with a benthic algal source in September 1996 
(Tables 4 \& 5), this was not the case in May 1997 (Figure 2b). However, other conspicuous invertebrate consumers, such as shrimp (Macrobrachium) and crayfish (Cherax), had $\delta^{13} \mathrm{C}$ values similar to benthic algae at all sites (Fig. 2, Table 4). The single pooled sample of chironomid larvae collected from leaf packs in Murken waterhole showed the most unusual carbon isotope signature of any of the consumers and was substantially more ${ }^{13} \mathrm{C}$-depleted than any of the measured primary sources $\left(\delta^{13} \mathrm{C}\right.$ $=-54.7 \%$ ).

Of the fish, Barcoo grunter (Scortum), spangled perch (Leiopotherapon), yellowbelly (Macquaria) and catfish (Neosilurus) had relatively ${ }^{13} \mathrm{C}$-enriched mean carbon isotope signatures, consistent with an ultimate dietary source of benthic algae (Fig.2, Table 4). Similarly, the two samples of turtle shell (Emydeura) also reflect a long-term feeding history on a ${ }^{13} \mathrm{C}$-enriched diet (Table 4). Other species of fish had carbon and nitrogen isotope values intermediate between the plankton and benthic algal signatures. Bony bream (Nematalosa) were consistently the most ${ }^{13} \mathrm{C}$-depleted of the fish collected.

Liver and bone samples of predatory fish (Macquaria and Leiopotherapon) were ${ }^{13} \mathrm{C}$-depleted compared with muscle tissue $(1.8 \pm 0.5 \%$ and $1.5 \pm 0.2 \%$, respectively). However, stable nitrogen isotope signatures of liver and bone samples showed no obvious difference to muscle tissue $(0.2 \pm 0.3 \%$ depletion and $0.4 \pm 0.2 \%$ enrichment, respectively).

Relationships between stable carbon isotope values of consumers and primary sources If benthic algae were an important source of organic carbon for the aquatic food web, we would expect the variability in $\delta^{13} \mathrm{C}$ values of consumers to track the observed variability 
in algal signatures. This was certainly the case for Macrobrachium where approximately $60 \%$ of the observed spatial and temporal variation in $\delta^{13} \mathrm{C}$ values was explained by variation in algal $\delta^{13} \mathrm{C}$ values $(\mathrm{r}=0.77, \mathrm{p}<0.001)$. A similar result was observed for predatory insects $(\mathrm{r}=0.82, \mathrm{p}=0.012)$ and, to a lesser extent, rainbow fish $(\mathrm{r}=0.46, \mathrm{p}=$ $0.045)$ and crayfish $(r=0.44, p=0.058)$. It is worth noting that there was comparatively little spatial or temporal variation in the carbon isotope values of terrestrial sources of organic carbon (leaves and CPOM) and no significant relationships were observed with the $\delta^{13} \mathrm{C}$ values of any consumer.

\section{Relationships between stable carbon and nitrogen isotope values of consumers}

Most species of fish showed a significant negative relationship between $\delta^{13} \mathrm{C}$ and $\delta^{15} \mathrm{~N}$ values (Table 6). In other words, ${ }^{13} \mathrm{C}$-depleted individuals were also ${ }^{15} \mathrm{~N}$-enriched, and were more similar to zooplankton isotope signatures than to CPOM or FPOM (Fig. 2). One possible explanation for this pattern is that it is size related and the ${ }^{13} \mathrm{C}$-depleted individuals were also larger and feeding higher in the food web (hence the elevated $\delta^{15} \mathrm{~N}$ values). This was not the case, however, and only one species (Retropinna) showed a positive relationship between body size and $\delta^{15} \mathrm{~N}$ values (Table 6). Of particular interest, was the observed negative relationship between $\delta^{15} \mathrm{~N}$ values and body size for bony bream (Nematalosa), which suggests that larger individuals of this species were feeding lower in the food web. Larger individuals of this species and rainbowfish (Melanotaenia) also tended to be more ${ }^{13} \mathrm{C}$-enriched (Table 6). 


\section{Contribution of benthic algal carbon to consumer biomass}

Estimates derived from the mixing models suggest an important contribution of benthic algal carbon to the biomass of most consumers, irrespective of whether the second primary source endpoint was zooplankton or terrestrial organic matter (Table 7). On average, most consumers derived at least $50 \%$ of their biomass from benthic algae and several species derived more than $70 \%$ across the study sites. The most notable exception was bony bream (Nematalosa) which, on average, derived only $25 \%$ of its biomass carbon from benthic algal sources. It is worth noting that the estimated contribution of algal carbon to consumer biomass in Murken sites was lower in September 1996 compared with May 1997 (Table 7).

At those sites where it was possible to estimate the relative contributions of all three sources, using $\delta^{13} \mathrm{C}$ and $\delta^{15} \mathrm{~N}$ values, it was apparent that terrestrial organic carbon was the other major contributor to the isotope signatures of crayfish (Cherax), shrimp (Macrobrachium) and catfish (Neosilurus spp). In contrast, zooplankton was the other major contributor to the diets of predatory fish, especially spangled perch (Leiopotherapon), Barcoo grunter (Scortum), yellowbelly (Macquaria), rainbowfish (Melanotaenia) and smelt (Retropinna). The isotope signatures of bony bream (Nematalosa) appeared to reflect a more even contribution of the three sources.

\section{Discussion}

\section{Productivity of waterholes}

Despite the extremely high natural turbidity, rates of benthic primary production along the littoral margins of waterholes of the Cooper Creek system were among the highest recorded for streams and rivers (Davies 1994; Bunn et al., 1997; Lamberti \& Steinman, 
1997). Similar high rates have been observed in other desert systems with sparse riparian cover (e.g. Lamberti \& Steinman, 1997; Mulholland et al., 2001), but were unexpected in systems characterised by such high turbidity. The ${ }^{13} \mathrm{C}$-enriched carbon isotope signatures of benthic algae, a likely consequence of carbon limitation, are also indicative of the high rates of primary production (Hicks, 1997; Finlay, 2001). Benthic primary production was, however, clearly light limited to a narrow littoral band with very low rates recorded in the deeper water. Marked diel variation in dissolved oxygen saturation in the open surface water also suggests high rates of phytoplankton production, though this was not directly measured. Even without factoring in this pelagic component, habitat-weighted estimates of whole system metabolism based on littoral and deeper channel measurements of benthic GPP and $\mathrm{R}_{24}$ suggest that almost all waterholes were autotrophic.

\section{Role of benthic algae in the food web}

Despite its limited extent, this 'bathtub ring' of benthic algae was clearly the most important source of organic carbon for consumers in waterholes. Many consumers had ${ }^{13} \mathrm{C}$-enriched isotope signatures reflecting a major contribution of this source to their biomass carbon. Furthermore, isotope signatures of some abundant consumers, particularly Macrobrachium, tracked observed spatial and temporal variability in benthic algal carbon signatures. Although the utility of carbon isotope tracing techniques has been questioned in the study of freshwater ecosystems because of the lack of a single consistent algal endpoint value (France, 1996), such relationships between consumers and algal isotope values provide compelling evidence of the importance of this source (Finlay, 2001). This is especially true when it is clear that similar relationships do not exist for other potential primary sources. 
The small differences observed between the stable isotope signatures of slow to fast turnover tissues (bone, muscle, liver) in predatory fish are more likely to reflect differences in tissue composition (e.g. lipid concentrations) rather than changes in diet isotope signatures over time (Hesslein et al., 1993). For example, the observed difference between liver and muscle tissue is similar to that observed in fish reared on commercial feed (Pinnegar \& Polunin, 1999). If anything, we would expect slow turnover tissue samples of fish caught in May 1997 to be more ${ }^{13} \mathrm{C}$-enriched, given the higher $\delta^{13} \mathrm{C}$ values for algae and consumers in September 1996 at the Murken waterhole. It is also worth noting that the two samples of turtle shell also reflect a long-term feeding history on a ${ }^{13} \mathrm{C}$-enriched source.

\section{Importance of other primary sources}

Carbon isotope data alone could not resolve the identity of the other major primary source that contributes to the biomass carbon of consumers with intermediate isotope values. The $\delta^{13} \mathrm{C}$ values of terrestrial organic matter (CPOM and riparian leaves) were too similar to those presumed for phytoplankton. Nitrogen isotope signatures were, however, useful given the marked difference in $\delta^{15} \mathrm{~N}$ values between these sources. Most predatory fish showed a strong negative relationship between $\delta^{13} \mathrm{C}$ and $\delta^{15} \mathrm{~N}$ values, implying that those with ${ }^{13} \mathrm{C}$-depleted signatures were more ${ }^{15} \mathrm{~N}$-enriched, consistent with a ${ }^{15} \mathrm{~N}$-enriched plankton endpoint. Estimates derived from the three-source mixing model, using $\delta^{13} \mathrm{C}$ and $\delta^{15} \mathrm{~N}$ data (Phillips \& Gregg, 2001), also support this view. Furthermore, conventional diet analysis of fish subsequently collected from these waterholes confirms a significant contribution of zooplankton (especially calanoid copepods) to the diet of predatory fish species (unpublished data). 
It is interesting to note that the size-related shifts in $\delta^{13} \mathrm{C}$ and $\delta^{15} \mathrm{~N}$ values of bony bream (Nematalosa), reflect a decreased dependence on plankton and a greater dependence on benthic algae and terrestrial detritus as they get larger. Dietary studies of this widespread and abundant species have previously suggested such a shift from planktivory to benthic detrital feeding (Allen, 1989). Similarly, rainbowfish (Melanotaenia) appear to shift to feeding from plankton to benthic sources as they get larger.

Due to the high concentrations of suspended sediment, we were unable to filter and isolate samples of phytoplankton and, as a consequence, were unable to identify the ultimate carbon source for zooplankton. We assume that phytoplankton were the likely source for several reasons. The surface water of waterholes in the mid channel was often supersaturated in dissolved oxygen during the day and $\mathrm{O}_{2}$-depleted during the late evening, suggesting high rates of primary production in the water column that cannot be attributed to the narrow benthic algal zone alone. Conspicuous blooms of phytoplankton also have been observed on the water surface of waterholes on occasions when there was little wind.

Despite the extensive riparian interface along the network of anastomosing channels and distributaries and the renowned floods that inundate vast floodplains, terrestrial carbon did not make an important contribution to the food web in the waterholes. Although it was the likely other endpoint for crayfish (Cherax), shrimp (Macrobrachium) and catfish (Neosilurus), the mixing model data suggest only about $20 \%$ of the biomass carbon of these species was of terrestrial origin. The relative high $\delta^{15} \mathrm{~N}$ values of the former two groups suggest that this contribution could be of animal origin rather than directly from leaf litter inputs. More sedentary primary consumers, 
such as mussels (Velesunio) and clams (Corbiculina) were the only taxa with isotope signatures consistent with a terrestrial (C3) source.

There is also evidence that some organic carbon from riparian leaf litter makes its way into the aquatic food web via methanogenic and methanotrophic bacteria. The extremely ${ }^{13} \mathrm{C}$-depleted values for chironomid larvae $\left(\delta^{13} \mathrm{C}=-54.7 \%\right.$ ) collected from benthic leaf packs in Murken waterhole can only have arisen through assimilation of methanotrophic bacteria (see Bunn \& Boon, 1993; Jones et al. 1999; Kiyashko, Narita \& Wada, 2001). This cannot be a major microbial pathway, however, because no higher order consumers show ${ }^{13} \mathrm{C}$-depletion beyond that of terrestrial organic matter and plankton.

\section{Models of ecosystem processes in large rivers}

These findings are clearly not consistent with predictions of two of the previously proposed ecosystem models of large rivers. There is no evidence of a strong dependence of the aquatic food web on direct riparian inputs to waterholes or from the many thousands of kilometers of small distributaries and anabranch channels upstream, as might be predicted by RCC (Vannote et al., 1980). Furthermore, despite the high turbidity in the waterholes, autotrophic production was still very high.

Similarly, episodic floods may re-distribute large amounts of terrestrial organic matter between the floodplain and the channels but this material does not find its way into the aquatic food web, as would be predicted by the FPC (Junk et al. 1989). This is not to say that floods are unimportant to other aspects of aquatic ecosystem function (e.g. the supply and mobilization of nutrients), the provision of extensive wetland habitat for waterbirds or to recruitment and dynamics of populations of fish and invertebrates 
(Walker et al., 1995; Kingsford, Curtin \& Porter, 1999; Puckridge, 1999; Roshier, Robertson \& Kingsford, 2002).

There is a growing body of evidence that microalgae are major drivers of aquatic food webs in large floodplain river systems, despite their apparently minor contribution to the total organic carbon pool compared with aquatic macrophytes and terrestrial sources (Forsberg et al., 1993; Hamilton, Lewis, \& Sippel 1992; Thorp et al., 1998; Benedito-Cecilio et al., 2000; Lewis et al., 2001; Thorp \& Delong, in press). Previous models of ecosystem processes in large rivers have understated this component of the system and instead over-emphasized the potential importance of longitudinal and lateral inputs of terrestrial carbon. Factors that influence the distribution, composition and production of microalgae (e.g. flow regulation, nutrients, light, toxic metals, herbicides, stock trampling) are likely to have a much greater impact on the food web of large river ecosystems than variations in the terrestrial carbon pool. These findings have important implications for the way in which we manage and protect large river ecosystems.

\section{Acknowledgments}

None of the work presented here would have been possible without the support and hospitality of the Windorah community. In particular, we wish to thank Dr Bob Morrish for his original invitation to visit the Cooper and take part in a workshop on the likely consequences of a controversial proposal to irrigate cotton. Sandy Kidd, Bill Scott and Bob Morrish kindly allowed us to work on their properties and provided a wealth of information on the local waterholes and flow history of the Cooper. The Queensland Environmental Protection Agency gave us permission to access sites located in Welford National Park and permits to collect. We thank Peter Fielder and the Queensland 
Department of Natural Resources and Mines Flow data for the provision of unpublished flow data for the Thomson and Barcoo Rivers. Chris Marshall and Bronwen Morrish provided assistance in the field, Sam Capon assisted with the preparation of the map of our sites and Thorsten Mosisch identified the algal samples. Fiona Balcombe, Christine Fellows, Stephen Hamilton and Fran Sheldon provided comments on early drafts of this manuscript. This project was funded by a grant from Land and Water Australia (GRU17) to SB as part of the National Riparian Lands Program.

\section{References}

Allen G.R. (1989) Freshwater Fishes of Australia. Neptune City: T.F.H. Publications. Anon. (1998) Draft Water Management Plan for Cooper Creek - Information paper.

Department of Natural Resources Queensland. pp 57. ISBN 072427278.

Bailey V. (2001) Western streams water quality monitoring project. Department of Natural Resources and Mines, Queensland, Australia. pp 42. ISBN 073451798 X.

Bayley P.B. (1995) Understanding large river-floodplain ecosystems. Bioscience, 45, 153158.

Bender M., Grande K., Johnson K., Marra J., Williams P.J.L., Sieburth J., Pilson M., Langdon C., Hitchcock G., Orchardo J., Hunt C., Donaghay P. \& Heinemann K. (1987) A comparison of four methods for determining planktonic community production. Limnology and Oceanography, 32, 1085-1098.

Benedito-Cecilio E., Araujo-Lima C.A.R.M., Forsberg B.R., Bittencourt M.M. \& Martinelli L.C. (2000) Carbon sources of Amazonian fisheries. Fisheries Management and Ecology, 7, 305-315. 
Boston H.L. \& Hill W.R. (1991) Photosynthesis-light relations of stream periphyton communities. Limnology and Oceanography, 36, 644-656.

Bott T.L., Brock J.J., Cushing C.E., Gregory S.V., King D. \& Petersen R.C. (1978) A comparison of methods for measuring primary productivity and community respiration in streams. Hydrobiologia, 60, 3-12.

Boyland D.E. (1984) Vegetation Survey of South West Queensland. Botany Bulletin No. 4, Queensland Herbarium.

Bunn S.E. \& Boon P.I. (1993) What sources of organic carbon drive food webs in billabongs? A study based on stable isotope analysis. Oecologia, 96, 85-94.

Bunn S.E. \& Davies P.M. (1999) Aquatic food webs in turbid, arid zone rivers: Preliminary data from Cooper Creek, Queensland. In: Free-flowing river: the ecology of the Paroo River (Ed. R.T. Kingsford), pp 67-76. New South Wales National Parks and Wildlife Service, Sydney. ISBN 0731360222.

Bunn S.E., Loneragan N.R. \& Kempster M.A. (1995) Effects of acid washing on stable isotope ratios of $\mathrm{C}$ and $\mathrm{N}$ in seagrass and penaeid shrimp: implications for food web studies using multiple stable isotopes. Limnology and Oceanography, 40, 622-625.

Bunn S.E., Davies P.M. \& Kellaway D.M. (1997) Contributions of sugar cane and invasive pasture grass to the aquatic food web of a tropical lowland stream. Marine and Freshwater Research, 48, 173-179.

Bunn S.E., Davies P.M., \& Mosisch T.D. (1999) Ecosystem measures of river health and their response to riparian and catchment degradation. Freshwater Biology, 41, 333345.

Capon S.J. (1998) Zonation of Floodplain Vegetation on a Flood Frequency Gradient In a Variable, Arid-zone Catchment. Honours Dissertation, Faculty of Environmental Sciences, Griffith University, Queensland, Australia. 
Cummins K.W. (1974) Structure and function of stream ecosystems. Bioscience, 24, 631- 641.

Davies B.R., Thoms M.C., Walker K.F., O’Keefe J.H. \& Gore J.A. (1995) Dryland rivers: their ecology, conservation and management. In: The Rivers Handbook, Vol. 2 (Eds P. Calow \& G.E. Petts), pp. 484-511. Blackwell Scientific, Oxford.

Davies P.M. (1994) Ecosystem ecology of upland streams of the northern jarrah forest, Western Australia. Unpublished PhD thesis, Department of Zoology, The University of Western Australia. pp 236.

Feminella J.W., Power M.E. \& Resh V.H. (1989) Periphyton responses to invertebrate grazing and riparian canopy in three northern California coastal streams. Freshwater Biology, 22, 445-457.

Finlay J.C. (2001) Stable-carbon-isotope ratios of river biota: implications for energy flow in lotic food webs. Ecology, 82, 1052-1064.

Forsberg B.R., Araujo-Lima C.A.R.M., Martinelli L.A., Victoria R.L. \& Bonassi J.A. (1993) Autotrophic carbon sources for fish of the central amazon. Ecology, 74, 643652.

France R.L. (1996) Carbon-13 conundrums: limitations and cautions in the use of stable isotope analysis in stream ecotonal research. Canadian Journal of Fisheries and Aquatic Sciences, 53, 1916-1919.

Gibling M.R., Nanson G.C. \& Maroulis J.C. (1998) Anastomosing river sedimentation in the channel country of central Australia. Sedimentology, 45, 595-619.

Graetz R.D. (1980) The potential applications of LANDSAT imagery to land resource management in the Channel Country. CSIRO Division of Land Resources Management, Perth, Western Australia. Technical Memo 80/2.

Gregory S.V., Swanson F.J., McKee W.A. \& Cummins K.W. (1991) An ecosystem perspective of riparian zones. Bioscience, 41, 540-551. 
Hamilton S.K., Lewis W.M.J. \& Sippel S.J. (1992) Energy sources for aquatic animals in the Orinoco River floodplain: evidence from stable isotopes. Oecologia, 89, 324330.

Hesslein R.H., Hallard K.A. \& Ramlal P. (1993) Replacement of sulfur, carbon, and nitrogen in tissue of growing broad whitefish (Coregonus nasus) in response to a change in diet traced by $\delta^{34} \mathrm{~S}, \delta^{13} \mathrm{C}$, and $\delta^{15} \mathrm{~N}$. Canadian Journal of Fisheries and Aquatic Sciences, 50, 2071-2076.

Hicks B.J. (1997) Food webs in forest and pasture streams in the Waikato region, New Zealand: a study based on analyses of stable isotope of carbon and nitrogen, and fish gut contents. New Zealand Journal of Marine and Freshwater Research, 31, 651664.

Johnson B.L., Richardson W.B. \& Naimo T.J. (1995) Past, present, and future concepts in large river ecology. Bioscience, 45, 134-141.

Jones R.I., Grey J., Sleep D. \& Arvola L. (1999) Stable isotope analysis of zooplankton carbon nutrition in humic lakes. Oikos, 86, 97-104.

Junk W.J., Bayley P.B. \& Sparks R.E. (1989) The flood pulse concept in river-floodplain systems. In: Proceedings of the international large river symposium. (Ed. D.P. Dodge) Canadian Special Publications Fisheries and Aquatic Sciences, 106, 110127.

Kingsford R.T., Curtin A.L. \& Porter J.L. (1999) Water flows on Cooper Creek determine 'boom' and 'bust' periods for waterbirds. Biological Conservation, 88, 231-248. 
Kiyashko S.I., Narita T. \& Wada E. (2001) Contribution of methanotrophs to freshwater macroinvertebrates: evidence from stable isotope ratios. Aquatic Microbial Ecology, 24, 203-207.

Knighton A.D. \& Nanson G.C. (1994) Flow transmission along an arid zone anastomosing river, Cooper Creek, Australia. Hydrological Processes, 8, 137-154.

Knighton A.D. \& Nanson G.C. (2001) An event-based approach to the hydrology of arid zone rivers in the Channel Country of Australia. Journal of Hydrology, 254, 102123.

Lambert W. (1984) The measurement of respiration. In: A Manual on Methods for the Assessment of Secondary Productivity in Fresh Waters. Second Edition. (Eds J.A. Downing and F.H. Rigler), pp 413-468. IBP Handbook 17, Blackwell Scientific Publications, Oxford.

Lamberti G.A. \& Steinman A.D. (1997) A comparison of primary production in stream ecosystems. Journal of the North American Benthological Society, 16, 95-103.

Lewis W.M., Hamilton S.K., Rodríguez M.A., Saunders III J.F. \& Lasi M.A. (2001) Foodweb analysis of the Orinoco floodplain based on production estimates and stable isotope data. Journal of the North American Benthological Society, 20, 241254.

Morton S.J., Short J. \& Baker R.D. (1995) Refugia for Biological Diversity in Arid and Semi-Arid Australia. Biodiversity Series, Paper No. 4. Report to the Biodiversity Unit of the Department of Environment, Sport and Territories. Canberra, Australia.

Mulholland P.J., Fellows C.S., Tank J.L., Grimm N.B., Webster J.R., Hamilton S.K., Martí E., Ashkenas L., Bowden W.B., Dodds W.K., McDowell W.H., Paul M.J. \& Peterson B.J. (2001) Inter-biome comparison of factors controlling stream metabolism. Freshwater Biology, 46, 1503-1517. 
Phillips D.L. (2001) Mixing models in analyses of diet using multiple stable isotopes: a critique. Oecologia, 127, 166-170.

Phillips D.L. \& Gregg J.W. (2001) Uncertainty in source partitioning using stable isotopes. Oecologia, 127, 171-179.

Pinnegar J.K. \& Polunin N.V.C. (1999) Differential fractionation of $\delta^{13} \mathrm{C}$ and $\delta^{15} \mathrm{~N}$ among fish tissues: implications for the study of trophic interactions. Functional Ecology, 13, 225-231.

Puckridge J.T. (1999) The role of hydrology in the biology of dryland rivers. In: Freeflowing river: the ecology of the Paroo River (Ed. R.T. Kingsford), pp 97-112. New South Wales National Parks and Wildlife Service, Sydney. ISBN 0731360222.

Puckridge J.T., Sheldon F., Walker K.F. \& Boulton A.J. (1998) Flow variability and the ecology of large rivers. Marine and Freshwater Research, 49, 55-72.

Rosenfeld J.S. \& Roff J.C. (1992) Examination of the carbon base in southern Ontario streams using stable isotopes. Journal of the North American Benthological Society, 11, 1-10.

Roshier D.A., Robertson A.I. \& Kingsford, R.T. (2002) Responses of waterbirds to flooding in an arid region of Australia and implications for conservation, Biological Conservation, 106, 399-411.

Thorp J.H. \& Delong M.D. (1994) The riverine productivity model: an heuristic view of carbon sources and organic matter processing in large river ecosystems. Oikos, 70, 305-308.

Thorp J.H. \& Delong M.D. (in press) Dominance of autochthonous autotrophic carbon in food webs in heterotrophic rivers. Oikos 
Thorp J.H., Delong M.D., Greenwood K.S. \& Casper A.F. (1998) Isotopic analysis of three food web theories in constricted and floodplain regions of a large river. Oecologia, 117, 551-563.

Thoms M.C. \& Sheldon F. (2000) Water resource development and hydrological change in a large dryland river: The Barwon-Darling River, Australia. Journal of Hydrology, 228, 10-21.

Vannote R.L., Minshall G.W., Cummins K.W., Sedell J.R. \& Cushing C.E. (1980) The river continuum concept. Canadian Journal of Fisheries and Aquatic Sciences, 37, 130-137.

Walker K.F., Sheldon F. \& Puckridge J.T. (1995) An ecological perspective on large dryland rivers. Regulated Rivers: Research and Management, 11, 85-104.

Winer B.J. (1971) Statistical Principles in Experimental Design. Second Edition. McGraw Hill, Tokyo. 
Table 1 Locations of the study sites sampled in the Cooper Creek catchment, in September 1996 and May 1997. Waterhole widths, taken at each site, and total lengths are also included

\begin{tabular}{|c|c|c|c|c|c|}
\hline Location/site & Site & Latitude & Longitude & $\begin{array}{c}\text { Length } \\
(\mathrm{km})\end{array}$ & $\begin{array}{c}\text { Width } \\
\text { (m) }\end{array}$ \\
\hline \multicolumn{6}{|l|}{$\underline{\text { Kyabra Creek }}$} \\
\hline One-mile waterhole & ID46 & S $25^{\circ} 50.4^{\prime}$ & E $143^{\circ} 03.0^{\prime}$ & 1.1 & 60 \\
\hline Springfield homestead & ID47 & S $25^{\circ} 49.2^{\prime}$ & E $143^{\circ} 02.4^{\prime}$ & 2.5 & 70 \\
\hline Moonbang Creek & ID48 & S $25^{\circ} 52.5^{\prime}$ & E $143^{\circ} 04.3^{\prime}$ & 0.6 & 15 \\
\hline \multicolumn{6}{|l|}{ Mayfield } \\
\hline Murken main channel & ID49 & S $25^{\circ} 25.2^{\prime}$ & E $142^{\circ} 44.1^{\prime}$ & 4.3 & 90 \\
\hline Murken distributary & ID50 & $\mathrm{S} 25^{\circ} 25.8^{\prime}$ & E $142^{\circ} 43.8^{\prime}$ & 0.8 & 20 \\
\hline Mayfield waterhole & ID51 & S $25^{\circ} 26.4^{\prime}$ & E $142^{\circ} 43.2^{\prime}$ & 0.6 & 35 \\
\hline \multicolumn{6}{|l|}{$\underline{\text { Tanbar }}$} \\
\hline Tanbar homestead & ID52 & S $25^{\circ} 50.4^{\prime}$ & E $141^{\circ} 54.6^{\prime}$ & 9.0 & 210 \\
\hline Tanbar bottom crossing & ID53 & $\mathrm{S} 25^{\circ} 52.2^{\prime}$ & E $141^{\circ} 52.8^{\prime}$ & 9.0 & 80 \\
\hline Tanbar distributary & ID54 & S $25^{\circ} 49.2^{\prime}$ & E $141^{\circ} 58.2^{\prime}$ & 1.4 & 80 \\
\hline \multicolumn{6}{|l|}{$\underline{\text { Barcoo-Welford }}$} \\
\hline Rosehill waterhole & ID55 & $\mathrm{S} 25^{\circ} 10.8^{\prime}$ & E $143^{\circ} 15.6^{\prime}$ & 4.5 & 80 \\
\hline Shearing shed & ID56 & S $25^{\circ} 11.4^{\prime}$ & E $143^{\circ} 12.0^{\prime}$ & 4.6 & 100 \\
\hline Barcoo homestead & ID57 & S $25^{\circ} 10.8^{\prime}$ & E $143^{\circ} 20.4^{\prime}$ & 1.7 & 70 \\
\hline
\end{tabular}


Table 2 Measurements of benthic metabolism at the four study locations in 1996 and 1997. GPP $=$ gross primary production (in $\mathrm{mg} \mathrm{C} \mathrm{m}^{-2}$ day $^{-1}$ ) and $\mathrm{R}_{24}=$ respiration (in $\mathrm{mg} \mathrm{C} \mathrm{m}{ }^{-2}$ day $\left.^{-1}\right)$. Values represent means $( \pm \mathrm{SEM}) . \quad \mathrm{DO}=$ range of open water dissolved oxygen saturation levels (in \%)

\begin{tabular}{lccllll}
\hline Location/site & Site & $\mathrm{n}$ & Habitat & GPP & $\mathrm{R}_{24}$ & DO \\
\hline Kyabra Creek (Sept. 1996) & & & & & & \\
One-mile waterhole & ID46 & 4 & Littoral & $2607(188)$ & $1682(129)$ & \\
& & 4 & Channel & $29(20)$ & $48(27)$ & \\
Springfield homestead & & & Reach & 158 & 130 & $27-165$ \\
& ID47 & 4 & Littoral & $2399(208)$ & $1600(207)$ & \\
& & 4 & Channel & $75(20)$ & $123(34)$ & \\
Moonbang Creek & & & Reach & 238 & 226 & $65-154$ \\
& ID48 & 8 & Littoral & $1514(81)$ & $894(106)$ & \\
& & 4 & Channel & $10(5)$ & $22(6)$ & \\
& & & Reach & 100 & 74 & $76-118$
\end{tabular}

$\underline{\text { Kyabra Creek (May 1997) }}$

One-mile waterhole

$\begin{array}{lllll}\text { ID46 } & 2 & \text { Littoral } & 2102(150) & 1134(126) \\ & 2 & \text { Channel } & 88(12) & 121(46) \\ & & \text { Reach } & 209 & 182\end{array}$

Springfield homestead

ID47 2 Littoral $2024(345) \quad 1506(204)$

1 Channel $24 \quad 44$

Reach $\quad 144 \quad 132$

Moonbang Creek

$\begin{array}{lllll}\text { ID48 } & 1 & \text { Littoral } & 68 & 101 \\ & 1 & \text { Channel } & 53 & 124 \\ & & \text { Reach } & 63 & 1230\end{array}$

Mayfield (Sept. 1996)

$\begin{array}{lllllll}\text { Murken main channel } & \text { ID49 } & 8 & \text { Littoral } & 4015(293) & 2088(230) & \\ & & 8 & \text { Channel } & 36(8) & 48(12) & \\ & & & \text { Reach } & 235 & 150 & 55-120 \\ \text { Murken distributory } & \text { ID50 } & 4 & \text { Littoral } & 3284(296) & 1705(434) & \\ & & 4 & \text { Channel } & 34(15) & 49(23) & \\ & & \text { Reach } & 294 & 181 & 59-133\end{array}$


$\underline{\text { Mayfield (May 1997) }}$

Murken main channel

Murken distributary

Mayfield waterhole

$\underline{\text { Tanbar (May 1997) }}$

Tanbar homestead

Tanbar bottom crossing

Tanbar distributory

Shearing shed

Barcoo Homestead

Rosehill waterhole

$\begin{array}{lllll}\text { ID49 } & 4 & \text { Littoral } & 2584(560) & 1555(306) \\ & 4 & \text { Channel } & 34(6) & 47(8) \\ & & \text { Reach } & 162 & 122\end{array}$

ID50 2 Littoral $2512(44) \quad 1617$ (167)

2 Channel 17 (5) 54 (9)

Reach $\quad 142 \quad 132$

$25-195$

$\begin{array}{llll}\text { ID51 } & 1 & \text { Littoral } & 3457\end{array}$

$1 \quad$ Channel $67 \quad 89$

Reach $238 \quad 208$

$\begin{array}{lllll}\text { ID52 } & 1 & \text { Littoral } & 2836 & 2102 \\ & 1 & \text { Channel } & 42 & 49 \\ & & \text { Reach } & 154 & 131\end{array}$

$57-121$

ID53 1 Littoral $1322 \quad 1331$

1 Channel $15 \quad 30$

Reach $\quad 80 \quad 95$

$76-118$

ID54 1 Littoral $2202 \quad 1634$

1 Channel $45 \quad 52$

Reach $153 \quad 131$

$80-127$

Barcoo-Welford (May 1997)

$\begin{array}{lllll}\text { ID55 } & 1 & \text { Littoral } & 1860 & 1028 \\ & 1 & \text { Channel } & 40 & 62 \\ & & \text { Reach } & 131 & 110 \\ \text { ID56 } & 1 & \text { Littoral } & 1550 & 985 \\ & 1 & \text { Channel } & 26 & 49 \\ & & \text { Reach } & 102 & 96\end{array}$

$67-115$

ID57 1 Littoral $1669 \quad 885$

Channel $19 \quad 40$

Reach $\quad 151 \quad 108$

$58-137$ 
Table 3 Three-way ANOVA on GPP, $R_{24}$ and P/R by location $(n=4)$, year $(n=2)$ and habitat $(n=2)$. GPP and $\mathrm{R}_{24}$ data were normalized by $\log (\ln )$ transformation and $\mathrm{P} / \mathrm{R}$ data were arcsine transformed. $* * * \mathrm{p}<0.001$, ** $\mathrm{p}<0.01$, * $\mathrm{p}<0.05$. The magnitude of treatment effects is shown as a percentage

\begin{tabular}{|c|c|c|c|c|c|c|}
\hline Parameter & Ln (GPF & & $\operatorname{Ln}\left(\mathrm{R}_{24}\right)$ & & Arcsine $\mathrm{P}$ & P/R \\
\hline Habitat (H) & $52.5 * * *$ & $(56 \%)$ & $55.8 * * *$ & $(62 \%)$ & $49.5 * * *$ & $(51 \%)$ \\
\hline Location (L) & $16.7^{*}$ & $(4 \%)$ & 12.6 & $(2 \%)$ & 11.7 & $(2 \%)$ \\
\hline Year (Y) & $49.6^{*}$ & $(5 \%)$ & 19.9 & $(3 \%)$ & 17.6 & $(3 \%)$ \\
\hline $\mathrm{H}^{*} \mathrm{~L}$ & 5.4 & $(<1 \%)$ & 5.1 & $(<1 \%)$ & 5.9 & $(<1 \%)$ \\
\hline $\mathrm{L} * \mathrm{Y}$ & 5.6 & $(<1 \%)$ & 5.0 & $(<1 \%)$ & 5.7 & $(<1 \%)$ \\
\hline $\mathrm{L}^{*} \mathrm{H}$ & 7.1 & $(<1 \%)$ & 6.6 & $(<1 \%)$ & 4.8 & $(<1 \%)$ \\
\hline $\mathrm{H}^{*} \mathrm{~L}^{*} \mathrm{Y}$ & 1.2 & $(<1 \%)$ & 1.1 & $(<1 \%)$ & 1.3 & $(<1 \%)$ \\
\hline Residual & 0.8 & $(33 \%)$ & 0.7 & $(31 \%)$ & 0.9 & $(42 \%)$ \\
\hline
\end{tabular}


Table 4 Stable carbon isotope ratios (\%) of sources and consumers from three sites at each of four locations in the Cooper Creek system.

Mean values ( \pm 1 SE, $n=3$ to 5 samples) or individual values are presented (where $n<3$ ). Data from sites indicated with an asterisk are plotted in Fig 2. ( ${ }^{\#}$ Turtle from Kyabra Creek was collected in September 1996)

\begin{tabular}{|c|c|c|c|c|c|c|c|c|c|c|c|c|c|c|c|}
\hline \multirow[b]{2}{*}{ Sample type } & \multicolumn{3}{|c|}{ Mayfield 1996} & \multicolumn{3}{|c|}{ Mayfield 1997} & \multicolumn{3}{|c|}{ Tanbar 1997} & \multicolumn{3}{|c|}{ Kyabra Creek 1997} & \multicolumn{3}{|c|}{ Barcoo-Welford 1997} \\
\hline & ID49 & ID50 & ID51 & ID49* & ID50 & ID51 & ID52* & ID53 & ID54 & ID46 & ID47* & ID48 & ID55 & ID56* & ID57 \\
\hline Riparian vegetation & $\begin{array}{l}-28.5 \\
(0.2)\end{array}$ & -26.6 & $\begin{array}{c}-28.9 \\
(0.2)\end{array}$ & $\begin{array}{c}-29.7 \\
(0.5)\end{array}$ & $\begin{array}{l}-31.6 \\
(0.5)\end{array}$ & $\begin{array}{c}-29.3 \\
(0.5)\end{array}$ & $\begin{array}{c}-27.0 \\
(2.3)\end{array}$ & $\begin{array}{r}-27.8 \\
(1.7)\end{array}$ & $\begin{array}{l}-28.7 \\
(0.4)\end{array}$ & $\begin{array}{c}-29.8 \\
(0.4)\end{array}$ & $\begin{array}{c}-28.6 \\
(0.2)\end{array}$ & $\begin{array}{c}-28.8 \\
(0.8)\end{array}$ & $\begin{array}{c}-27.0 \\
(1.2)\end{array}$ & $\begin{array}{l}-27.9 \\
(0.9)\end{array}$ & $\begin{array}{c}-28.0 \\
(2.1)\end{array}$ \\
\hline СРОМ & $\begin{array}{c}-26.8 \\
(0.1)\end{array}$ & $\begin{array}{c}-27.0 \\
(0.5)\end{array}$ & $\begin{array}{l}-26.8 \\
(0.2)\end{array}$ & $\begin{array}{c}-32.6 \\
(0.4)\end{array}$ & $\begin{array}{l}-29.5 \\
(0.1)\end{array}$ & $\begin{array}{l}-27.8 \\
(0.1)\end{array}$ & $\begin{array}{l}-28.8 \\
(0.5)\end{array}$ & $\begin{array}{l}-28.4 \\
(0.2)\end{array}$ & $\begin{array}{l}-29.3 \\
(0.5)\end{array}$ & $\begin{array}{l}-28.8 \\
(0.5)\end{array}$ & $\begin{array}{l}-32.7 \\
(0.9)\end{array}$ & $\begin{array}{l}-29.5 \\
(0.8)\end{array}$ & $\begin{array}{c}-30.4 \\
(0.8)\end{array}$ & $\begin{array}{c}-32.5 \\
(0.9)\end{array}$ & $\begin{array}{l}-31.9 \\
(0.9)\end{array}$ \\
\hline FPOM & $\begin{array}{c}-26.3 \\
(0.1)\end{array}$ & $\begin{array}{c}-26.2 \\
(0.3)\end{array}$ & $\begin{array}{l}-25.6 \\
(0.3)\end{array}$ & $\begin{array}{l}-25.9 \\
(0.2)\end{array}$ & $\begin{array}{c}-26.6 \\
(0.1)\end{array}$ & $\begin{array}{c}-25.4 \\
(0.5)\end{array}$ & $\begin{array}{c}-26.0 \\
(0.1)\end{array}$ & $\begin{array}{c}-24.7 \\
(0.2)\end{array}$ & $\begin{array}{l}-25.8 \\
(0.1)\end{array}$ & $\begin{array}{c}-26.2 \\
(0.1)\end{array}$ & $\begin{array}{c}-26.4 \\
(0.2)\end{array}$ & $\begin{array}{l}-25.7 \\
(0.3)\end{array}$ & $\begin{array}{c}-23.9 \\
(0.1)\end{array}$ & $\begin{array}{c}-25.8 \\
(0.1)\end{array}$ & $\begin{array}{c}-25.1 \\
(0.6)\end{array}$ \\
\hline Littoral algae & $\begin{array}{c}-16.0 \\
(0.8)\end{array}$ & $\begin{array}{c}-19.0 \\
(0.8)\end{array}$ & $\begin{array}{c}-14.5 \\
(0.1)\end{array}$ & $\begin{array}{c}-18.9 \\
(0.5)\end{array}$ & $\begin{array}{c}-18.9 \\
(0.6)\end{array}$ & $\begin{array}{l}-17.0 \\
(1.6)\end{array}$ & $\begin{array}{l}-22.5 \\
(1.3)\end{array}$ & -22.1 & $\begin{array}{l}-20.5 \\
(0.2)\end{array}$ & - & $\begin{array}{c}-24.0 \\
(1.4)\end{array}$ & $\begin{array}{c}-24.2 \\
(0.1)\end{array}$ & - & $\begin{array}{l}-17.7 \\
(1.1)\end{array}$ & $\begin{array}{c}-19.3 \\
(0.3)\end{array}$ \\
\hline Zooplankton & - & - & - & $\begin{array}{c}-28.5 \\
(0.7)\end{array}$ & - & - & $\begin{array}{l}-30.7 \\
(0.3)\end{array}$ & -31.1 & $\begin{array}{c}-27.2 \\
(0.7)\end{array}$ & - & - & - & - & $\begin{array}{c}-34.2 \\
(0.4)\end{array}$ & - \\
\hline Notopala & $\begin{array}{c}-15.4 \\
(0.1)\end{array}$ & $\begin{array}{c}-18.5 \\
(1.0)\end{array}$ & $\begin{array}{l}-23.4 \\
-23.6\end{array}$ & $\begin{array}{l}-25.5 \\
-27.2\end{array}$ & $\begin{array}{l}-26.1 \\
-28.8\end{array}$ & -26.2 & - & - & - & $\begin{array}{l}-26.9 \\
-26.7\end{array}$ & $\begin{array}{l}-24.3 \\
-25.1\end{array}$ & - & - & - & - \\
\hline Velesunio & - & - & - & -30.9 & -30.4 & - & - & - & - & $\begin{array}{l}-27.5 \\
(0.1)\end{array}$ & -27.8 & - & - & - & - \\
\hline Corbiculina & - & - & - & - & -32.1 & - & - & - & - & -28.5 & -29.0 & - & - & - & - \\
\hline Chironomidae & -54.7 & & & & & & & & & & & & & & \\
\hline Invertebrate predators & - & -21.4 & -22.0 & - & - & - & -26.8 & -25.9 & - & -24.4 & -25.3 & -25.4 & - & - & -22.9 \\
\hline
\end{tabular}




\begin{tabular}{|c|c|c|c|c|c|c|c|c|c|c|c|c|c|c|c|}
\hline Macrobrachium & $\begin{array}{l}-18.7 \\
(0.5)\end{array}$ & $\begin{array}{c}-19.6 \\
(0.8)\end{array}$ & $\begin{array}{l}-18.0 \\
(0.3)\end{array}$ & $\begin{array}{l}-19.6 \\
-21.2\end{array}$ & $\begin{array}{l}-20.6 \\
(0.1)\end{array}$ & $\begin{array}{c}-20.6 \\
(0.4)\end{array}$ & $\begin{array}{l}-22.4 \\
-23.7\end{array}$ & $\begin{array}{l}-22.0 \\
-24.2\end{array}$ & $\begin{array}{l}-22.8 \\
(0.8)\end{array}$ & $\begin{array}{l}-23.2 \\
(0.3)\end{array}$ & $\begin{array}{l}-22.0 \\
(0.3)\end{array}$ & $\begin{array}{l}-25.5 \\
(0.5)\end{array}$ & $\begin{array}{l}-21.3 \\
-19.8\end{array}$ & $\begin{array}{l}-23.6 \\
(0.2)\end{array}$ & $\begin{array}{l}-21.3 \\
(0.6)\end{array}$ \\
\hline Cherax & $\begin{array}{l}-21.4 \\
-20.7\end{array}$ & $\begin{array}{l}-20.6 \\
-20.5\end{array}$ & -19.2 & - & - & - & - & - & - & $\begin{array}{l}-23.1 \\
(0.5)\end{array}$ & $\begin{array}{l}-22.0 \\
-21.3\end{array}$ & $\begin{array}{l}-23.8 \\
(0.2)\end{array}$ & - & $\begin{array}{l}-23.9 \\
(0.5)\end{array}$ & $\begin{array}{l}-22.3 \\
(0.5)\end{array}$ \\
\hline Nematalosa & -26.8 & - & -25.7 & $\begin{array}{c}-24.9 \\
(1.0)\end{array}$ & $\begin{array}{l}-25.1 \\
(1.5)\end{array}$ & $\begin{array}{c}-24.8 \\
(1.0)\end{array}$ & $\begin{array}{l}-27.1 \\
-26.7\end{array}$ & $\begin{array}{l}-28.7 \\
-26.4\end{array}$ & & $\begin{array}{l}-27.6 \\
(1.1)\end{array}$ & $\begin{array}{l}-27.5 \\
(0.2)\end{array}$ & $\begin{array}{c}-30.3 \\
(0.4)\end{array}$ & & $\begin{array}{l}-30.9 \\
(1.3)\end{array}$ & $\begin{array}{l}-24.7 \\
(2.3)\end{array}$ \\
\hline Leiopotherapon & - & - & - & $\begin{array}{l}-21.0 \\
-19.5\end{array}$ & $\begin{array}{l}-21.0 \\
-22.1\end{array}$ & -20.6 & - & - & - & $\begin{array}{l}-24.2 \\
(0.6)\end{array}$ & -21.3 & $\begin{array}{l}-23.1 \\
(0.5)\end{array}$ & - & $\begin{array}{l}-23.1 \\
(0.3)\end{array}$ & - \\
\hline Melanotaenia & - & -24.1 & - & $\begin{array}{l}-22.3 \\
-22.1\end{array}$ & $\begin{array}{l}-21.6 \\
-19.7\end{array}$ & -20.2 & $\begin{array}{l}-21.8 \\
-21.5\end{array}$ & $\begin{array}{c}-23.3 \\
(0.5)\end{array}$ & $\begin{array}{l}-22.5 \\
(0.2)\end{array}$ & $\begin{array}{l}-22.5 \\
-22.6\end{array}$ & -23.4 & -22.9 & - & -24.4 & -22.3 \\
\hline Ambassis & - & - & - & - & -23.9 & - & - & - & - & $\begin{array}{l}-24.9 \\
-26.5\end{array}$ & -25.2 & -28.4 & - & $\begin{array}{l}-26.0 \\
-25.6\end{array}$ & $\begin{array}{c}-26.0 \\
(0.2)\end{array}$ \\
\hline Neosilurus spp. & - & - & - & $\begin{array}{l}-22.5 \\
(0.5)\end{array}$ & $\begin{array}{l}-21.3 \\
(1.2)\end{array}$ & $\begin{array}{l}-23.4 \\
-21.4\end{array}$ & $\begin{array}{l}-24.0 \\
-19.0\end{array}$ & -21.7 & -19.9 & - & $\begin{array}{l}-23.4 \\
-21.6\end{array}$ & -27.3 & - & - & - \\
\hline Retropinna & $\begin{array}{l}-24.7 \\
-24.9\end{array}$ & $\begin{array}{l}-24.4 \\
-24.7\end{array}$ & $\begin{array}{l}-23.9 \\
-24.5\end{array}$ & -19.9 & - & - & - & $\begin{array}{l}-26.2 \\
-25.8\end{array}$ & -25.7 & $\begin{array}{l}-25.2 \\
-25.2\end{array}$ & -25.7 & $\begin{array}{l}-25.7 \\
-25.9\end{array}$ & - & -26.8 & - \\
\hline Macquaria & $\begin{array}{l}-26.5 \\
-19.3\end{array}$ & $\begin{array}{l}-21.5 \\
-21.7\end{array}$ & $\begin{array}{l}-24.3 \\
-26.2\end{array}$ & $\begin{array}{l}-20.8 \\
(0.5)\end{array}$ & $\begin{array}{l}-20.1 \\
-21.7\end{array}$ & - & $\begin{array}{l}-20.2 \\
-21.4\end{array}$ & - & - & - & -25.2 & -28.2 & - & $\begin{array}{l}-23.0 \\
-23.5\end{array}$ & - \\
\hline Scortum & -23.2 & -23.0 & -26.1 & $\begin{array}{l}-22.2 \\
(2.5)\end{array}$ & -21.8 & $\begin{array}{l}-21.3 \\
-23.1\end{array}$ & $\begin{array}{c}-21.3 \\
(1.2)\end{array}$ & $\begin{array}{c}-22.3 \\
(0.6)\end{array}$ & $\begin{array}{l}-20.8 \\
-21.8\end{array}$ & - & - & - & - & - & - \\
\hline Hypseleotris & $\begin{array}{l}-23.3 \\
-22.3\end{array}$ & $\begin{array}{l}-21.3 \\
(0.5)\end{array}$ & $\begin{array}{l}-21.3 \\
-21.5\end{array}$ & - & - & - & - & - & - & $\begin{array}{l}-25.0 \\
-25.2\end{array}$ & $\begin{array}{l}-25.7 \\
(0.3)\end{array}$ & - & - & $\begin{array}{l}-29.4 \\
-27.5\end{array}$ & $\begin{array}{l}-26.5 \\
-24.9\end{array}$ \\
\hline Gambusia & -21.3 & - & - & - & - & - & $\begin{array}{l}-24.0 \\
-24.4\end{array}$ & $\begin{array}{c}-23.8 \\
(0.4)\end{array}$ & - & - & - & - & - & -19.8 & -21.6 \\
\hline Emydeura & & -22.4 & & & & & & & & & $-19.3^{\#}$ & & & & \\
\hline
\end{tabular}


Table 5 Stable nitrogen isotope ratios (\%) of sources and consumers from three sites at each of four locations in the Cooper Creek system. Other details as per Table 4

\begin{tabular}{|c|c|c|c|c|c|c|c|c|c|c|c|c|c|c|c|}
\hline \multirow[b]{2}{*}{ Sample type } & \multicolumn{3}{|c|}{ Mayfield 1996} & \multicolumn{3}{|c|}{ Mayfield 1997} & \multicolumn{3}{|c|}{ Tanbar 1997} & \multicolumn{3}{|c|}{ Kyabra Creek 1997} & \multicolumn{3}{|c|}{ Barcoo-Welford 1997} \\
\hline & ID49 & ID50 & ID51 & ID49* & ID50 & ID51 & ID52* & ID53 & ID54 & ID46 & ID $47 *$ & ID48 & ID55 & ID56* & ID57 \\
\hline Riparian vegetation & $\begin{array}{c}7.0 \\
(0.8)\end{array}$ & 7.7 & $\begin{array}{c}4.1 \\
(0.9)\end{array}$ & $\begin{array}{l}10.0 \\
(2.7)\end{array}$ & $\begin{array}{c}9.8 \\
(3.0)\end{array}$ & $\begin{array}{c}8.7 \\
(2.1)\end{array}$ & $\begin{array}{c}7.7 \\
(3.0)\end{array}$ & $\begin{array}{l}11.5 \\
(1.5)\end{array}$ & $\begin{array}{c}8.2 \\
(0.9)\end{array}$ & $\begin{array}{c}2.7 \\
(1.4)\end{array}$ & $\begin{array}{c}4.3 \\
(1.6)\end{array}$ & $\begin{array}{c}9.6 \\
(2.4)\end{array}$ & $\begin{array}{c}5.5 \\
(2.2)\end{array}$ & $\begin{array}{l}11.2 \\
(0.8)\end{array}$ & $\begin{array}{c}7.7 \\
(0.8)\end{array}$ \\
\hline СРОМ & $\begin{array}{c}7.2 \\
(0.2)\end{array}$ & $\begin{array}{c}7.6 \\
(0.4)\end{array}$ & $\begin{array}{c}8.1 \\
(0.4)\end{array}$ & $\begin{array}{c}7.7 \\
(0.8)\end{array}$ & $\begin{array}{c}7.5 \\
(0.4)\end{array}$ & $\begin{array}{c}7.3 \\
(0.9)\end{array}$ & $\begin{array}{c}7.9 \\
(0.8)\end{array}$ & $\begin{array}{c}9.9 \\
(0.4)\end{array}$ & $\begin{array}{c}6.9 \\
(0.6)\end{array}$ & $\begin{array}{c}8.4 \\
(0.4)\end{array}$ & $\begin{array}{c}8.9 \\
(0.4)\end{array}$ & $\begin{array}{c}6.1 \\
(0.3)\end{array}$ & $\begin{array}{c}8.8 \\
(0.3)\end{array}$ & $\begin{array}{c}8.9 \\
(0.5)\end{array}$ & $\begin{array}{c}7.3 \\
(0.4)\end{array}$ \\
\hline FPOM & $\begin{array}{c}6.2 \\
(0.4)\end{array}$ & $\begin{array}{c}7.6 \\
(0.3)\end{array}$ & $\begin{array}{c}7.5 \\
(0.4)\end{array}$ & $\begin{array}{c}7.7 \\
(0.5)\end{array}$ & $\begin{array}{c}7.5 \\
(0.5)\end{array}$ & $\begin{array}{c}7.6 \\
(1.4)\end{array}$ & $\begin{array}{c}8.7 \\
(0.2)\end{array}$ & $\begin{array}{c}8.6 \\
(0.8)\end{array}$ & $\begin{array}{c}8.0 \\
(1.0)\end{array}$ & $\begin{array}{c}7.0 \\
(0.3)\end{array}$ & $\begin{array}{c}7.6 \\
(0.4)\end{array}$ & $\begin{array}{c}5.1 \\
(0.4)\end{array}$ & $\begin{array}{c}8.2 \\
(0.9)\end{array}$ & $\begin{array}{c}9.7 \\
(0.8)\end{array}$ & $\begin{array}{c}8.6 \\
(0.9)\end{array}$ \\
\hline Littoral algae & $\begin{array}{c}7.8 \\
(0.4)\end{array}$ & $\begin{array}{c}8.6 \\
(0.7)\end{array}$ & $\begin{array}{c}8.9 \\
(0.2)\end{array}$ & $\begin{array}{c}6.4 \\
(0.3)\end{array}$ & $\begin{array}{c}6.9 \\
(0.7)\end{array}$ & $\begin{array}{c}5.9 \\
(0.6)\end{array}$ & $\begin{array}{c}4.9 \\
(1.1)\end{array}$ & 7.8 & $\begin{array}{c}6.5 \\
(0.7)\end{array}$ & - & $\begin{array}{c}9.4 \\
(0.4)\end{array}$ & $\begin{array}{c}9.6 \\
(1.4)\end{array}$ & - & $\begin{array}{l}11.2 \\
(1.9)\end{array}$ & $\begin{array}{c}9.6 \\
(0.3)\end{array}$ \\
\hline Zooplankton & - & - & - & $\begin{array}{l}17.3 \\
(1.3)\end{array}$ & - & - & $\begin{array}{l}12.5 \\
(0.5)\end{array}$ & 10.7 & $\begin{array}{l}10.7 \\
(0.4)\end{array}$ & - & - & - & - & $\begin{array}{l}14.8 \\
(0.4)\end{array}$ & - \\
\hline Notopala & $\begin{array}{c}8.5 \\
(0.1)\end{array}$ & $\begin{array}{c}9.4 \\
(0.2)\end{array}$ & $\begin{array}{l}9.0 \\
9.2\end{array}$ & $\begin{array}{c}9.8 \\
12.5\end{array}$ & $\begin{array}{c}9.9 \\
11.5\end{array}$ & 11.0 & - & - & - & $\begin{array}{l}9.9 \\
8.4\end{array}$ & $\begin{array}{c}9.5 \\
11.1\end{array}$ & - & - & - & - \\
\hline Velesunio & - & - & - & 12.7 & 12.0 & - & - & - & - & $\begin{array}{c}9.5 \\
(0.3)\end{array}$ & 11.6 & - & - & - & - \\
\hline Corbiculina & - & - & - & - & 12.6 & - & - & - & - & 8.9 & 11.5 & - & - & - & - \\
\hline Chironomidae & 12.6 & & & & & & & & & & & & & & \\
\hline Invertebrate predators & - & 9.7 & 12.2 & - & - & - & 6.6 & 6.6 & - & 9.2 & 10.1 & 9.2 & - & - & 9.4 \\
\hline
\end{tabular}




\begin{tabular}{|c|c|c|c|c|c|c|c|c|c|c|c|c|c|c|c|}
\hline Macrobrachium & $\begin{array}{l}12.9 \\
(0.2)\end{array}$ & $\begin{array}{l}12.6 \\
(0.4)\end{array}$ & $\begin{array}{l}12.1 \\
(0.1)\end{array}$ & $\begin{array}{l}12.9 \\
13.2\end{array}$ & $\begin{array}{l}13.2 \\
(0.3)\end{array}$ & $\begin{array}{l}14.2 \\
(0.2)\end{array}$ & $\begin{array}{l}10.1 \\
10.9\end{array}$ & $\begin{array}{c}9.9 \\
10.7\end{array}$ & $\begin{array}{l}10.4 \\
(0.2)\end{array}$ & $\begin{array}{l}12.2 \\
(0.1)\end{array}$ & $\begin{array}{l}13.3 \\
(0.2)\end{array}$ & $\begin{array}{l}12.1 \\
(0.4)\end{array}$ & $\begin{array}{l}14.9 \\
14.6\end{array}$ & $\begin{array}{l}12.5 \\
(0.2)\end{array}$ & $\begin{array}{l}11.9 \\
(0.2)\end{array}$ \\
\hline Cherax & $\begin{array}{l}11.5 \\
12.2\end{array}$ & $\begin{array}{l}11.6 \\
13.0\end{array}$ & 12.3 & - & - & - & - & - & - & $\begin{array}{l}11.0 \\
(0.4)\end{array}$ & $\begin{array}{l}12.6 \\
11.5\end{array}$ & $\begin{array}{l}12.0 \\
(1.1)\end{array}$ & - & $\begin{array}{l}11.7 \\
(0.3)\end{array}$ & $\begin{array}{l}11.0 \\
(0.7)\end{array}$ \\
\hline Nematalosa & 14.2 & - & 14.3 & $\begin{array}{l}11.6 \\
(1.4)\end{array}$ & $\begin{array}{l}12.0 \\
(1.9)\end{array}$ & $\begin{array}{l}10.1 \\
(0.8)\end{array}$ & $\begin{array}{l}8.4 \\
9.5\end{array}$ & $\begin{array}{c}10.0 \\
9.7\end{array}$ & & $\begin{array}{l}11.2 \\
(1.1)\end{array}$ & $\begin{array}{l}13.3 \\
(0.3)\end{array}$ & $\begin{array}{l}12.9 \\
(0.4)\end{array}$ & & $\begin{array}{l}12.9 \\
(0.3)\end{array}$ & $\begin{array}{l}10.8 \\
(0.3)\end{array}$ \\
\hline Leiopotherapon & - & - & - & $\begin{array}{c}11.1 \\
8.6\end{array}$ & $\begin{array}{l}12.3 \\
14.3\end{array}$ & 8.8 & - & - & - & $\begin{array}{l}13.7 \\
(0.2)\end{array}$ & 11.5 & $\begin{array}{l}13.6 \\
(0.4)\end{array}$ & - & $\begin{array}{l}13.7 \\
(0.2)\end{array}$ & - \\
\hline Melanotaenia & - & 12.2 & - & $\begin{array}{l}12.2 \\
12.1\end{array}$ & $\begin{array}{l}12.5 \\
10.3\end{array}$ & 8.4 & $\begin{array}{l}9.5 \\
9.5\end{array}$ & $\begin{array}{c}9.9 \\
(0.6)\end{array}$ & $\begin{array}{l}10.5 \\
(0.5)\end{array}$ & $\begin{array}{l}11.5 \\
11.7\end{array}$ & 12.4 & 12.3 & - & 13.0 & 12.1 \\
\hline Ambassis & - & - & - & - & 12.6 & - & - & - & - & 11.6 & 12.7 & 14.4 & - & $\begin{array}{l}12.3 \\
12.9\end{array}$ & $\begin{array}{l}12.0 \\
(0.2)\end{array}$ \\
\hline Neosilurus spp. & - & - & - & $\begin{array}{c}9.5 \\
(0.8)\end{array}$ & $\begin{array}{l}10.1 \\
(1.7)\end{array}$ & $\begin{array}{l}8.7 \\
8.3\end{array}$ & $\begin{array}{l}9.9 \\
7.1\end{array}$ & 9.1 & 7.4 & - & $\begin{array}{l}12.3 \\
11.2\end{array}$ & 13.0 & - & - & - \\
\hline Retropinna & $\begin{array}{l}14.6 \\
14.9\end{array}$ & $\begin{array}{l}14.3 \\
13.4\end{array}$ & $\begin{array}{l}15.0 \\
14.8\end{array}$ & 8.4 & - & - & - & $\begin{array}{l}12.1 \\
12.1\end{array}$ & 12.2 & $\begin{array}{l}13.8 \\
13.7\end{array}$ & 14.4 & $\begin{array}{l}13.8 \\
14.4\end{array}$ & - & 12.8 & - \\
\hline Macquaria & $\begin{array}{l}15.3 \\
15.1\end{array}$ & $\begin{array}{l}14.1 \\
13.2\end{array}$ & $\begin{array}{l}14.7 \\
15.2\end{array}$ & $\begin{array}{l}12.2 \\
(0.7)\end{array}$ & $\begin{array}{l}10.6 \\
11.0\end{array}$ & - & $\begin{array}{l}11.9 \\
12.2\end{array}$ & - & - & - & 13.9 & 14.2 & - & $\begin{array}{l}15.6 \\
15.0\end{array}$ & - \\
\hline Scortum & 13.1 & 13.3 & 14.2 & $\begin{array}{c}8.4 \\
(1.0)\end{array}$ & 11.9 & $\begin{array}{l}11.4 \\
11.7\end{array}$ & $\begin{array}{c}9.9 \\
(1.2)\end{array}$ & $\begin{array}{l}10.7 \\
(0.8)\end{array}$ & $\begin{array}{l}7.2 \\
8.3\end{array}$ & - & - & - & - & - & - \\
\hline Hypseleotris & $\begin{array}{l}14.4 \\
13.4\end{array}$ & $\begin{array}{l}14.1 \\
(0.2)\end{array}$ & $\begin{array}{l}13.9 \\
14.4\end{array}$ & - & - & - & - & - & - & $\begin{array}{l}12.3 \\
12.6\end{array}$ & $\begin{array}{l}13.3 \\
(0.1)\end{array}$ & - & - & $\begin{array}{l}12.1 \\
12.5\end{array}$ & $\begin{array}{l}11.8 \\
12.2\end{array}$ \\
\hline Gambusia & 14.8 & - & - & - & - & - & $\begin{array}{l}10.1 \\
10.0\end{array}$ & $\begin{array}{l}10.8 \\
(0.2)\end{array}$ & - & - & - & - & - & 14.4 & 13.6 \\
\hline Emydeura & & 15.0 & & & & & & & & & $14.5^{\#}$ & & & & \\
\hline
\end{tabular}


Table 6 Pearson correlation coefficients and associated levels of significance for relationships between stable carbon and nitrogen isotope values (\%) of fish, and isotope values $\left(\delta^{13} \mathrm{C}, \delta^{15} \mathrm{~N}\right)$ and fish size $(\mathrm{cm}) .{ }^{*} \mathrm{p}<0.05, * * \mathrm{p}<0.01, * * * \mathrm{p}<0.001$, $\mathrm{n}=$ sample size

\begin{tabular}{|c|c|c|c|c|}
\hline Fish species & & $\delta^{13} \mathrm{C} v s \delta^{15} \mathrm{~N}$ & Size $v s \delta^{13} \mathrm{C}$ & Size $v s \delta^{15} \mathrm{~N}$ \\
\hline & $\mathrm{n}$ & $\mathrm{r}$ & $\mathrm{r}$ & $\mathrm{r}$ \\
\hline Ambassis & 10 & $-0.58 *$ & 0.24 & 0.43 \\
\hline Nematalosa & 26 & $-0.51 * *$ & $0.43^{*}$ & $-0.58 * *$ \\
\hline Leiopotherapon & 18 & $-0.77 * * *$ & -0.01 & 0.31 \\
\hline Retropinna & 10 & $-0.78 * *$ & -0.48 & $0.66^{*}$ \\
\hline Macquaria & 11 & $-0.64 *$ & 0.28 & 0.16 \\
\hline Neosilurus & 16 & $-0.63 * *$ & -0.11 & $0.49 *$ \\
\hline Scortum & 14 & $-0.48^{*}$ & 0.18 & 0.01 \\
\hline Hypseleotris & 9 & 0.33 & 0.37 & 0.08 \\
\hline Melanotaenia & 17 & -0.32 & $0.61 * *$ & -0.11 \\
\hline All fish & 134 & $-0.45 * * *$ & - & - \\
\hline
\end{tabular}


Table 7 Percent benthic algal contribution to consumer diets at four locations in the Cooper Creek catchment using either a two-source mixing model $\left(\delta^{13} \mathrm{C}, \mathrm{CPOM}\right)$ or three-source model ( $\delta^{13} \mathrm{C}$ and $\delta^{15} \mathrm{~N}, \mathrm{CPOM}$ and plankton). Fractionation coefficients used were adjusted for estimated trophic position $\left({ }^{\mathrm{a}}=0.2\right.$ and $1.5 \%{ }^{\mathrm{b}}=0.3$ and 3.0 $\%$, ${ }^{\mathrm{c}}=0.4$ and $4.5 \%$, for $\delta^{13} \mathrm{C}$ and $\delta^{15} \mathrm{~N}$, respectively). The range of values represents variation among sites and mean values (and $1 \mathrm{SE}$ ) have been calculated using the estimated benthic algal contribution at each site

\begin{tabular}{|c|c|c|c|c|c|c|}
\hline Consumer & $\begin{array}{c}\text { Murken } \\
1996\end{array}$ & $\begin{array}{c}\text { Murken } \\
1997\end{array}$ & Tanbar & $\begin{array}{c}\text { Kyabra } \\
\text { Creek }\end{array}$ & $\begin{array}{l}\text { Barcoo- } \\
\text { Welford }\end{array}$ & $\begin{array}{c}\text { Mean \% } \\
(1 \mathrm{SE})\end{array}$ \\
\hline Notopala $^{\mathrm{a}}$ & $29-100$ & $13-44$ & - & 90 & - & $56(15)$ \\
\hline Macrobrachium ${ }^{\mathrm{b}}$ & $69-88$ & $64-87$ & $62-89$ & $70-100$ & $58-82$ & $78(4)$ \\
\hline Cherax ${ }^{\mathrm{b}}$ & $51-76$ & - & - & 100 & $56-74$ & $82(11)$ \\
\hline Predatory insects & $37-66$ & - & $27-35$ & $70-82$ & 69 & $55(8)$ \\
\hline Nematalosa ${ }^{\mathrm{b}}$ & $0-8$ & $25-54$ & $0-43$ & $0-56$ & $9-55$ & $25(7)$ \\
\hline Leiopotherapon ${ }^{\mathrm{c}}$ & - & $62-88$ & & 100 & $61-65$ & $80(6)$ \\
\hline Melanotaenia $^{c}$ & 30 & $62-80$ & $64-100$ & 100 & $52-73$ & $75(6)$ \\
\hline Ambassis $^{\mathrm{c}}$ & - & 49 & - & $13-82$ & $43-44$ & $46(11)$ \\
\hline Neosilurus ${ }^{\mathrm{c}}$ & - & $46-74$ & 100 & $34-100$ & - & $78(9)$ \\
\hline Retropinna $^{\mathrm{c}}$ & $15-25$ & $85-90$ & $16-53$ & $62-76$ & $36-42$ & $43(9)$ \\
\hline Macquaria $^{\mathrm{c}}$ & $11-62$ & $76-83$ & 100 & $17-82$ & $60-64$ & $56(10)$ \\
\hline Scortum $^{\mathrm{c}}$ & $2-44$ & $48-73$ & $82-100$ & - & - & $60(11)$ \\
\hline Hypseleotris ${ }^{\mathrm{c}}$ & $33-66$ & - & - & 76 & $24-46$ & $48(8)$ \\
\hline Gambusia $^{\mathrm{c}}$ & 46 & - & $66-78$ & - & $79-85$ & $68(6)$ \\
\hline
\end{tabular}


Fig. 1 Map of the Cooper Creek catchment showing study sites. Location and site names are as in Table 1.

Fig. $2 \delta^{13} \mathrm{C}$ and $\delta^{15} \mathrm{~N}$ values of primary sources and consumers from one site at each of four locations within the Cooper Creek catchment in October 1997: (a) Springfield homestead (ID47), Kyabra Creek; (b) Murken waterhole (ID49), Mayfield; (c) Tanbar waterhole (ID52), Tanbar; and (d) Shearing shed waterhole (ID56), Barcoo-Welford. Potential primary sources are plotted as boxes +1 SE about the mean, where $n=3$ samples. Consumers plotted are: $\boldsymbol{\Gamma}$ insect predators (Anisoptera and Dytiscidae), () snails (Notopala), $\leftarrow$ mussels (Velesunio), $\downarrow$ shrimps (Macrobrachium), crayfish (Cherax), and fish ( $\lambda$ Nematalosa, $\sigma$ Leiopotherapon, $v$ Melanotaenia, $\tau$ Ambassis, $\mathrm{H}$ Neosilurus, 9 Retropinna, $\varpi$ Macquaria). Means are plotted with $\pm 1 \mathrm{SE}$ as boxes for sources and bars for consumers, where $\mathrm{n}=3$ to 5 samples. 


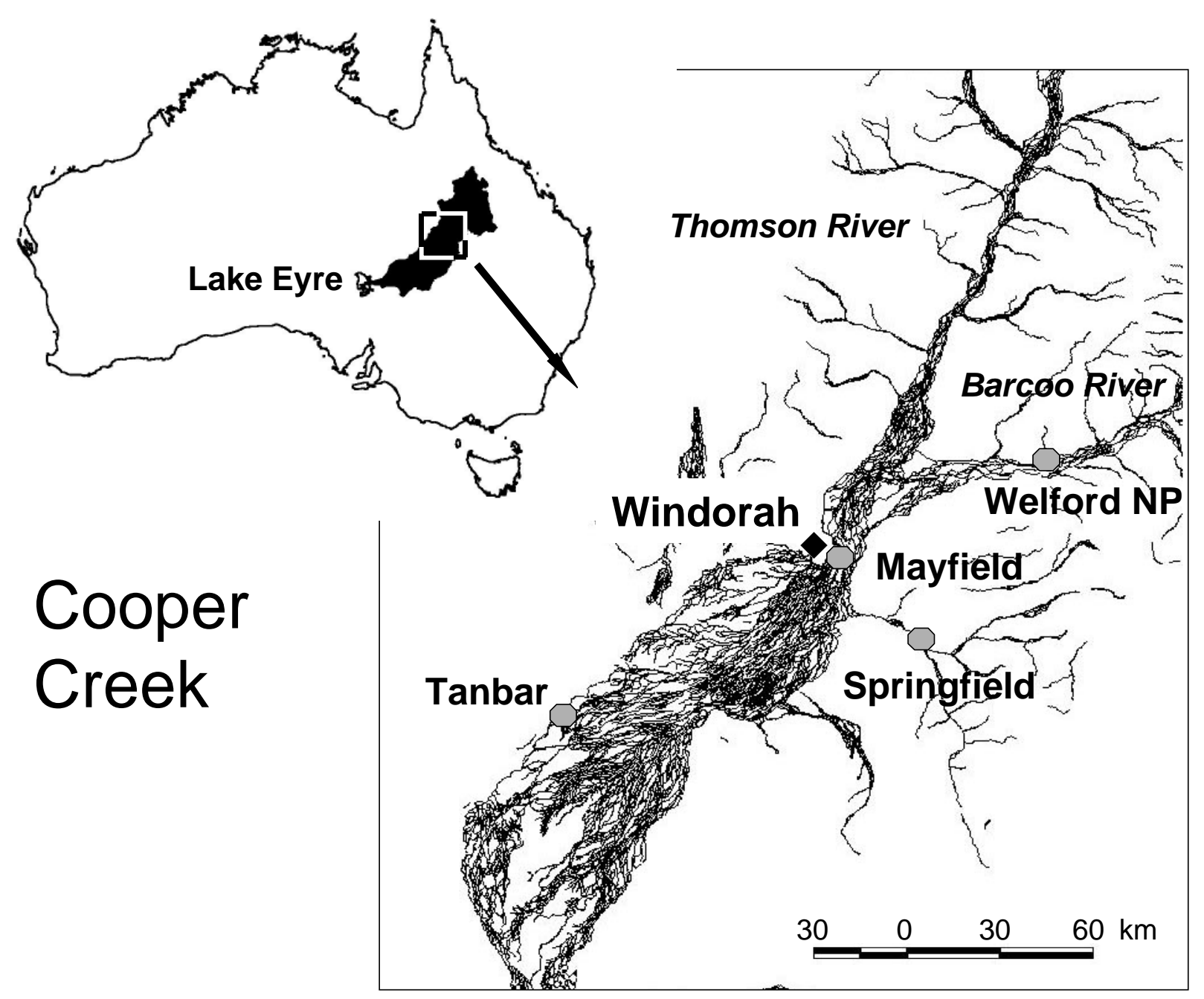




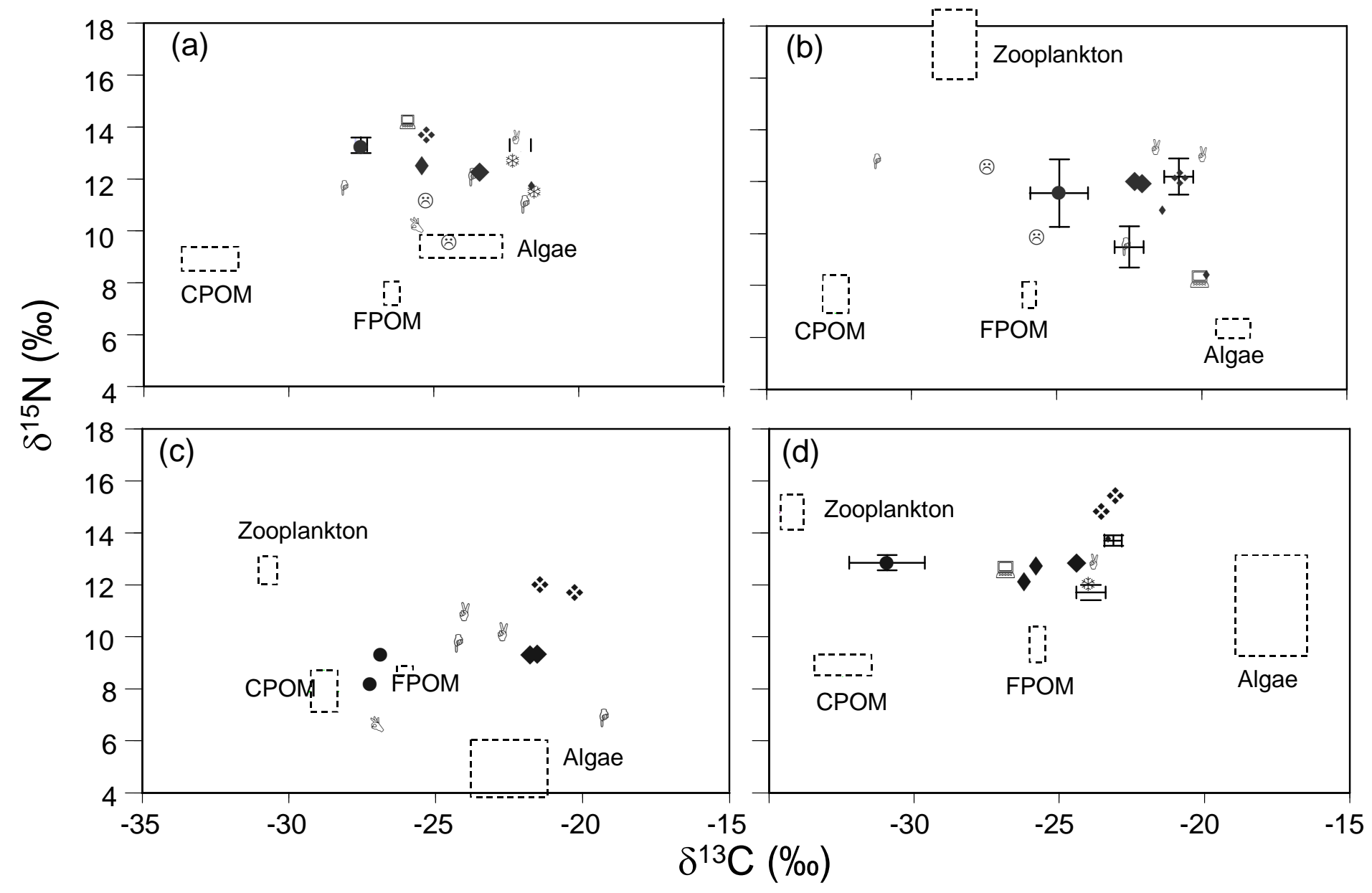

